\title{
Intercultural Competence in the Eyes of State School English Language Teachers in Turkey
}

\author{
Nur Gedik Bal ${ }^{1}$, Perihan Savas ${ }^{2}$ \\ ${ }^{1}$ Social Sciences University of Ankara \\ ${ }^{2}$ Middle East Technical University
}

\begin{abstract}
Correspondence concerning this article should be addressed to Nur Gedik Bal, School of Foreign Languages, Social Sciences University of Ankara, Yabancı Diller Yüksekokulu. Hükümet Meydanı No: 2 06050 UlusAnkara, Turkey.E-mail: nur.gedikbal@asbu.edu.tr
\end{abstract}

\begin{abstract}
Equipping students with intercultural competence (hereafter IC) is a critical aim of English foreign language classrooms nowadays, and EFL teachers have emerged as essential players for accomplishing this. These teachers should essentially be competent in their intercultural skills so that they can pass these on to their students in order to foster interculturally competent language learners. However, teachers' perceptions regarding IC remain uncertain, particularly in the Turkish context. Thus, before asking teachers to apply methods and strategies so that they can enhance students' IC in the classroom, it is vital that we investigate what they understand about IC. Therefore, this qualitative study aimed to reveal middle and high school teachers' understanding of the IC phenomenon and their description of the characteristics of an interculturally competent foreign language learner and teacher. In addition, teachers' perceptions regarding their own and their learners' IC were also explored in this study. The participants were 30 middle and high school English language teachers teaching at state schools in Turkey. Semi-structured interviews were conducted to collect the data. MAXQDA was exploited in order to analyse the data, primarily to code, categorize, and systematize the findings. The results indicated that the teachers considered IC to be the ability to communicate with people from various cultures effectively, having knowledge about one's own, target, and other cultures, and developing positive attitudes toward other cultures and societies. They also emphasized the inseparability of language and culture and the importance of English as an international language. The teachers also indicated why they viewed themselves and their learners as interculturally competent or incompetent, which could provide insight into where to start intercultural learning and teaching in foreign language classrooms and how to train EFL teachers about different dimensions of IC.
\end{abstract}

Keywords: english as a foreign language, intercultural competence, interculturally competent language learner, intercultural education, cultural awareness

\section{Introduction}

\section{Definition of IC}

Considering all the various perspectives in different sub-disciplines of intercultural communication, intercultural competence has been identified by many terms such as intercultural sensitivity, global competence, cultural proficiency, cultural intelligence, cross-cultural effectiveness, cross-cultural relations, cross-cultural adaptation, and so forth. Despite the lack of consensus on the concept, it is widely accepted among researchers and practitioners that intercultural competence is the primary dexterity to be able to live and work with people from different cultures (Hammer, 2015).

Rathje (2007) defines IC as the general culture competency necessary in interactions between people from various societies encountering foreignness in order to produce culture by gaining familiarity and cohesion among the individuals. Fantini (2009) and Bennett and Bennett (2004) similarly define IC as the complex competences that are needed in the effective and appropriate interaction among linguistically and culturally different people. Spitzberg and Changnon (2009) also emphasize the interaction aspect and describe IC as the 
ability to manage the interaction between people who are divergent in terms of 'affective, cognitive, and behavioural orientations to the world' (p.7).

Viewing the IC as a developmental process similar to Bennett and Bennett (2004) and Fantini (2009), Hammer (2015) defines IC as the ability to change one's cultural perspective and adapt their actions properly to cultural commonalities and differences.

Chen and Starosta (2000) also differentiate the terms cultural awareness, intercultural sensitivity, and intercultural adroitness and these three constitute the umbrella term: intercultural communicative competence. Cultural awareness is the cognitive dimension, which is primarily about the awareness of the effect of culture on how we think and behave, whereas intercultural sensitivity is the affective aspect, which is the incentive to accept differences among cultures. Intercultural adroitness is the behavioural aspect i.e. the ability to realize communicative goals in an intercultural interaction. Similarly, Risager (2007) refers to the three domains of knowledge, skills, and attitudes.

However, Risager (2007) differentiates cultural competence from intercultural competence. Whereas cultural competence refers to the knowledge, skills, and attitudes of a specific culture based on target language country, IC is defined as the knowledge, skills, and attitudes at the interface between several cultures including one's own culture and target culture. Mughan (1999) also claims that IC allows learners to prepare for 'exposure to all cultures, not just the one whose language is learned' (p.64). Moreover, Kramsch (1993) and Byram (1997, 2008, and 2012) also acknowledge that IC is not the knowledge of a particular culture but the knowledge and skills enabling a learner to communicate with the people from other cultures and contexts. Byram's (1997) intercultural communicative competence (ICC) model is a comprehensive one, which is primarily acknowledged in English as a foreign language (EFL) teaching contexts for defining IC. In this study, the researchers adopt Byram's (1997) model of ICC to define intercultural competence.

\section{Byram's (1997) Model of Intercultural Communicative Competence}

Byram's (1997) model of ICC is primarily based on the idea of communicative competence introduced by Hymes (1972) and developed by Canale and Swain (1980) and 'communicative ability' defined by van Ek (1986). Grounded in Hymes' (1972) ideas, Canale and Swain (1980) suggested that communicative competence consisted of three different competences: grammatical competence, sociolinguistic competence, and strategic competence. Canale (1982) also added discourse competence in addition to these later. Van Ek (1986) also had a similar typology of the competences that are required to model communicative ability. It included six competences, some of which were in line with the competences stated by Canale and Swain (1980). The six competences of van Ek (1986), which underlay Byram's Model of ICC in 1990s, included linguistic, sociolinguistic, discourse, strategic, sociocultural, and social competence.

Byram's model of ICC had two separate parts: one is communicative competence and the latter is the intercultural competence. The communicative competence section included the competences introduced by Canale and Swain (1980) and van Ek (1986) in their revised versions, whereas the latter part included intercultural competence, which was more related to the social and sociocultural competence introduced by van Ek (1986).

The intercultural competence model developed by Byram and Zarate (1997) specifically for the Common European Framework of Reference for Languages (CEFR) included:

- Attitudes (savoir etre): curiosity, openness, readiness to suspend disbelief about other cultures

- Knowledge (saviors): knowledge of social groups, their practices, products, etc.

- Skills of relating and interpreting (savoir comprendre): the ability to relate and interpret a text from another culture

- Skills of discovery and interaction (savoir apprendre/faire): ability to acquire new knowledge of culture and the ability to operate under real-time constraints

- Critical cultural awareness (savoir s'engager): Evaluating one's own culture and other cultures critically (Byram, Gribkova \& Starkey, 2002, p.12-13) 


\section{Interculturally competent EFL learner}

In the light of the turn from cultural to intercultural, Byram (2012) asserts that interculturalism is indeed needed to become an intercultural speaker. Intercultural speakers need both IC and linguistic/communicative competence while mediating between various languages and cultures. In other words, the competence, which an intercultural speaker has, is profoundly different from what a native speaker has. The improvement in the status of an intercultural speaker is not a development towards perfection in a foreign language as opposed to an ideal native speaker (Wilkinson, 2012).

Byram (2008) acknowledges that an intercultural speaker can be renamed as an intercultural mediator; however, he wants to maintain 'speaker' because of the importance attached to language. That is, an intercultural mediator can be an intercultural speaker, reader, and writer. He/she is expected to negotiate cultural boundaries both in written and spoken interaction (Wilkinson, 2012). Elena (2014) also regards foreign language proficiency as a passport for an individual's intercultural integration just as Aba's (2016) emphasis on the necessity of proficiency in a foreign language and Moeller and Faltin Osborn's (2014) consideration of communicative competence as a significant asset.

One of the Jackson's (2014) characteristics of effective intercultural communicators is to be sensitive to cultural beliefs, values, and gender differences. Attitudes such as openness to cultural otherness, respect, and empathy are also regarded as essential competences that need to be acquired by learners if they are to live in culturally various societies (Council of Europe, 2016). Fantini (2000) also acknowledge common traits that are listed for the profile of an interculturally competent person that include empathy, respect, openness, curiosity, and flexibility.

\section{Interculturally competent EFL teacher}

In MoNE's (2017) General Competencies for Teaching Profession, specifically under the domain of National, Moral, and Universal Values, teachers are expected to respect both individual and cultural differences. Marczak (2013) also acknowledges that tolerance, acceptance of otherness, and openness are some qualifications of an intercultural teacher. Brunsmeier (2017) primarily emphasizes the importance of teachers' being sensitive to their learners' attitudes, as it is considered the base for intercultural learning processes.

According to Marczak (2013), a teacher is required to be ready to encounter situations where they are puzzled and not able to respond to the questions of their students. In order to manage such a challenge, teachers need to have some common knowledge and insight in relation to the target culture. Some other scholars (Ho, 2009; Kaçar, 2019; Kızılaslan, 2010) also emphasize that a teacher should have enough knowledge of their own native culture to promote intercultural competence for language learners. In addition to attitudes and knowledge, Marczak (2013) asserts that an interculturally successful teacher needs to possess skills in materials management as well.

\section{A brief review of similar studies}

There are many studies on teachers' IC practices in EFL classrooms (Atay, 2005; Brunsmeier, 2017; Cansever \& Mede, 2016; Demircioğlu \& Çakır, 2015; Han \& Song, 2011; Kılıç, 2013; Kuru Gönen \& Sağlam, 2012; Sercu, 2005); however, few of them focused on what teachers really understand from terms like culture (Bayyurt, 2006) and intercultural competence (Brunsmeier, 2017) and their self-assessment in terms of IC. They primarily used a survey tool to investigate the teachers' perceptions and practices of intercultural language teaching and the studies were mainly conducted in a tertiary context. Therefore, only the most relevant studies will be presented here.

In other contexts, Han and Song (2011) conducted a study on English university instructors' understanding of ICC in a Chinese context and a questionnaire adapted from previous studies was implemented with 30 instructors. The results revealed restricted amounts of intercultural teaching due to teachers' unfamiliarity with certain aspects of the target culture and inadequate intercultural elements in materials. Brunsmeier (2017) conducted a study to reveal how primary school teachers approach ICC where problem-based interviews were conducted with 19 teachers all over Germany. The teachers were asked to bring a task that they believe 
can help promote ICC and describe the task to help learn about their practices and understandings. The findings revealed that $74 \%$ of the teachers regarded attitudes such as openness, curiosity, and tolerance as prerequisites for ICC. The cognitive dimension was also emphasized by all the teachers. Considering the skills of interpreting and relating, only half of the participants referred to the similarities and differences between the home and target culture.

In the Turkish context, Bayyurt (2006) conducted a study on English teachers' perceptions of culture and interviews were conducted with 12 private and state school teachers. They were asked to define culture and the results indicated that they primarily focused on lifestyles, traditions, history, rituals, and festivals to define culture concepts. Most of the participants emphasized the strong connection between culture and language teaching. Demircioğlu and Çakır (2015) also investigated international college teachers' perspectives and attitudes towards IC teaching. Their curriculum is based on IC skills, so teachers practiced IC teaching through tasks and activities. Teachers also regarded traditions and values as the most important dimension of culture; however, these researchers also called for similar studies in state schools.

To summarize, the studies which investigated teachers' understandings of IC and self-assessment in relation to IC were limited to tertiary education and private schools in the Turkish context. Therefore, there is a need to explore state school teachers' understanding of IC to interpret their IC teaching practices and identify their professional needs in further studies.

\section{Statement of purpose and the research questions}

Equipping students with intercultural competence is a critical aim of foreign language classrooms nowadays because of developing technology, migration, and globalization in every field. In order to have interculturally competent language learners who are able to communicate effectively with individuals from other cultures in intercultural situations, it is essential that teachers are competent in their intercultural skills so that they can pass these on to their students (Catalano, 2014; Crozet \& Liddicoat 1997; Deardorff, 2009; Demircioğlu \& Çakır, 2015; Doğançay-Aktuna, 2005; Ghanem, 2017; Kaçar, 2019; Marczak, 2013; Sercu, 2006).

However, before asking them to be interculturally competent and apply the methods and strategies so that they can enhance students' IC in the classroom, it is vital that we probe into what they know about IC or how they define it first. Even though IC was defined in many different ways by various scholars (i.e. Bennett \& Bennett, 2004; Byram, 1997; Chen and Starosta, 2000; Deardorf, 2009; Fantini, 2000; Kramsch, 2003; Risager, 2007; Spitzberg and Changnon, 2009), it is also important to find out what the teachers understand about IC as they are the practitioners who equip learners with such skills.

The studies carried out in the Turkish context primarily investigated teachers' perceptions and practices of culture teaching in EFL classrooms and mainly in tertiary context (Cansever \& Mede, 2016; Gönen \& Sağlam, 2012; Kılıç, 2013) and private institutions (Demircioğlu \& Çakır, 2015) rather than public middle and high schools and they were primarily based on a survey. This particular study, therefore, aimed to understand public middle and high school teachers' deeper understanding of the concept via the interviewing technique.

Furthermore, the study aimed to reveal their self-assessments regarding IC. It is significant to find out how teachers see themselves as intercultural speakers so that some training programs might be developed to help those who need further development in IC. It is also important to reveal their perceptions of their learners' IC in order to help them identify their learners' needs and develop some complementary tools and teaching strategies to further develop their learners' IC. Therefore, the research questions were:

1. How do state school English language teachers in Turkey describe:

a) intercultural competence (IC),

b) an interculturally competent EFL learner,

c) and an interculturally competent EFL teacher?

2. What are the teachers' perceptions regarding their own and their learners' intercultural competence? 


\section{Methods}

\section{Design of the study}

This qualitative study primarily draws on the principles of Interpretative Phenomenological Analysis (IPA) since the study aimed to reveal teachers' understanding of the intercultural competence phenomenon that is encountered and experienced by teachers in their teaching of a foreign language. This design is a combination of phenomenology and hermeneutics which end up being descriptive as they are concerned with how things appear. It is also interpretative as the researchers take an active role interpreting the participants' experiences and trying to make sense of the participants' worlds (Pietkiewicz and Smith, 2012). The researchers studied a group of teachers and revealed themes created in the analysis and exemplified them with participants' personal narratives.

\section{Participants}

The sampling strategy was purposeful sampling because of the intrinsic nature of phenomenological studies and the research questions. Some studies (Behrnd \& Porzelt, 2012; Dwyer, 2004) indicated that the length of stay abroad had an impact on individuals' intercultural competence. Therefore, the first criterion was the length of the English language teachers' study/work abroad experiences as this might be one variable having an impact on the understandings, beliefs, and practices of the teachers. Therefore, a demographic survey was shared on social networking sites and teachers were asked to fill it in. Volunteer teachers who had less than sixmonth overseas experience (including people who had none) were contacted.

The second criterion was the context in which the teachers were working. Only state school teachers working at middle and high schools were taken into consideration as the private institutions and universities would have totally different student profiles, curricula, and materials and this would not fit the homogeneity of a phenomenological study. There were also many studies conducted on teachers' views regarding IC in university context, but there are fewer studies in middle and high schools.

As a result, the participants were 30 English language teachers teaching at middle and high schools in Turkey. There were five male and 25 female teachers. Their ages ranged between 24 and 44.25 of the teachers were graduates of Departments of English Language Teaching. Three were graduates in Linguistics, and the other two were graduates of Translation and Interpretation and Departments of English Language and Literature. Their teaching experiences ranged between three and 21 years. Out of the 30, 12 teachers did not have overseas experience. The overseas experience of 15 teachers was less than a month.

Teachers from different regions of Turkey attended the study. The details regarding the number of participants attending from different cities in Turkey can be examined in Figure 1 below.

\section{Figure 1}

\section{Teaching context of the teachers}

\begin{tabular}{|c|c|c|c|c|c|c|}
\hline $\begin{array}{c}\text { Central } \\
\text { Anatolian }\end{array}$ & $\begin{array}{c}\text { Eastern } \\
\text { Anatolia }\end{array}$ & $\begin{array}{l}\text { South-eastern } \\
\text { Anatolia }\end{array}$ & $\begin{array}{c}\text { Black Sea } \\
\text { Region }\end{array}$ & $\begin{array}{l}\text { Mediterranean } \\
\text { Region }\end{array}$ & $\begin{array}{c}\text { Marmara } \\
\text { Region }\end{array}$ & $\begin{array}{l}\text { Aegean } \\
\text { Region }\end{array}$ \\
\hline $\begin{array}{c}\text { Ankara } \\
\text { (F:5) }\end{array}$ & \multirow{2}{*}{$\begin{array}{l}\text { Ağrı } \\
\text { (F:1) }\end{array}$} & \multirow{2}{*}{$\begin{array}{l}\text { Şanlıurfa } \\
\text { (F:1) }\end{array}$} & $\begin{array}{l}\text { Zonguldak } \\
\text { (F:1) }\end{array}$ & \multirow{3}{*}{$\begin{array}{c}\text { Kahraman } \\
\text { maraş } \\
(\mathrm{F}: 3)\end{array}$} & $\begin{array}{c}\text { İstanbul } \\
\text { (F:5) }\end{array}$ & \multirow{2}{*}{$\begin{array}{c}\text { Afyon } \\
\text { (F:1) }\end{array}$} \\
\hline $\begin{array}{c}\text { Konya } \\
\text { (F:1) }\end{array}$ & & & $\begin{array}{l}\text { Kocaeli } \\
\text { (F:1) }\end{array}$ & & $\begin{array}{c}\text { Sakarya } \\
(F: 4)\end{array}$ & \\
\hline $\begin{array}{l}\text { Nevşehir } \\
\text { (F:1) }\end{array}$ & $\begin{array}{c}\text { Erzurum } \\
(\mathrm{F}: 1)\end{array}$ & $\begin{array}{l}\text { Şırnak } \\
\text { (F:1) }\end{array}$ & $\begin{array}{l}\text { Çorum } \\
\text { (F:1) }\end{array}$ & & $\begin{array}{l}\text { Bursa } \\
(\mathrm{F}: 2)\end{array}$ & $\begin{array}{l}\text { Izmir } \\
\text { (F:1) }\end{array}$ \\
\hline
\end{tabular}


Out of the 30 teachers, six of the teachers expressed that they did not have any courses regarding IC or cultural aspects of language teaching. Sixteen of them indicated that they did not have a specific course named intercultural competence or cultural aspects of language teaching, but they thought that these topics were covered in other courses such as English Language and Literature, American Culture and Literature, Language and Culture, Intercultural Communication, Sociolinguistics, Language Transfer, Language Acquisition, Bilingualism, Youth Projects, and CEFR seminars.

\section{Data collection tool and process}

As stated by Creswell (2007), in-depth interviews are common tools for phenomenological studies. Specifically, semi-structured interviews not only provide a dialogue in real time but also have flexibility when unexpected issues arise for the researcher to investigate deeper with further questioning (Pietkiewicz \& Smith, 2012). Therefore, the main data were collected through semi-structured interviews. The interview questions were piloted with three teachers before the actual study was conducted. During the interviews, all of the teachers were asked the same main questions for the systematicity of the procedure and the questions were in line with the research questions. However, impromptu questions were also asked in line with the nature of the semistructured interviews.

The interviews were carried out in Turkish to make the teachers feel comfortable and avoid the impact of restricted language use on the revelations of the teachers. Member checking during the interviews was done through insistent questioning. Since this study was a part of a bigger project, the total duration of the interviews was 1015 minutes and an interview lasted 34 minutes on average. The data was collected over five months. Participants identities were kept confidential by representing them in the data as P1, P2, P3 etc. (i.e. P1= Participant 1). For ethical concerns, the Human Subjects Ethics Committee of a state university and the Ministry of National Education of the Republic of Turkey Directorate General of Innovation and Educational Technologies were asked to examine the proposed study, specifically demographic survey, and the interview questions, and the authors received their approval. Debriefing sessions with the thesis supervisor and thesis committee members were conducted throughout the research study.

\section{Data analysis}

Data analysis was based on IPA and the process included certain steps. Firstly, transcriptions were done verbatim, and then transcriptions of 15 interviews, half of the data collected, were checked by a third party to ensure accuracy.

Next, close reading and re-reading of transcriptions was conducted. Initial open coding was carried out via the MAXQDA program. Each code was identified based on the teachers' actual words which were then turned into primarily nouns. Colour coding was also used for the codes and some memos were taken on the codes in the program.

An English instructor at a university was asked to code 10\% of the data for inter-coder reliability. There were not any significant differences in codes and categories except for the fact that the authors' codes were more detailed.

The codes were clustered based on the theoretical framework and research questions in MAXQDA. When the preliminary themes, categories, and codes were identified, they were clustered in tables. Then the findings were interpreted based on these detailed tables and previous studies. The sample excerpts were translated into English. Transcriptions were also crosschecked.

\section{Results}

In order to explore teachers' views of IC and how they define it in an EFL context, the teachers were asked to define the IC concept in relation to language learning and teaching. They were also asked about the characteristics of an interculturally competent EFL learner and teacher, and finally they evaluated their own IC. 
The interviews revealed similar concepts in the definition of IC and interculturally competent EFL learners and teachers; however, while describing an interculturally competent teacher, participants also emphasized teaching skills to integrate IC in their classes, which will be examined in the following sub-sections more thoroughly.

\section{Intercultural competence in the eyes of EFL teachers}

While the teachers were describing IC in relation to English language learning and teaching, they mentioned certain components of IC including knowledge, attitudes, skills of relating and interpreting, and skills of interaction and discovery as shown in Table 1.

\section{Table 1}

Participants' definition of intercultural competence

\begin{tabular}{lcc}
\hline & Categories and sample codes & f \\
\hline 1. Attitudes & & 20
\end{tabular}

(e.g. acceptance, empathy, openness, respect, etc.)

2. Knowledge

(e.g. knowledge of target and home cultures i.e. their clothes, cuisines, religion, habits, and traditions)

3. Skills of interpreting and relating

(e.g. comparison between cultures, critical thinking, understanding other cultures)

4. Skills of discovery and interaction

(e.g. the ability to communicate in English, adapting to new cultures, behaving appropriately, impact of culture on communication, etc.)

The teachers pointed to various attitudes to define IC. These attitudes included empathy, acceptance of similarities and differences, respect, and openness. IC was also defined as the knowledge of the home culture (i.e. Turkish culture), and target culture (i.e. British/American culture). Participants indicated that culture involves special days, lifestyles, clothes, cuisine, religion, cultural heritage, and habits. Some participants also emphasized the significance of comparing these two cultures and being integrated with other cultures, as well. The participant teachers also referred to the understanding of other cultures and being aware of the differences, which was listed under the category of 'skills of relating and interpreting' in Table 1.

One of the common explanations used to define IC was the ability to interact or communicate with people from other cultures. The teachers also believed in the necessity of behaving appropriately based on the other cultures' values or differences between the cultures. Considering all the definitions provided by the teachers, P4's definition of IC was a comprehensive summary referring to almost all the categories revealed during the interviews.

I think intercultural competence is the ability to communicate with individuals from other cultures effectively and accurately and understanding the relationship that we construct. For instance, it is the ability to accept the similarities and differences in other cultures different from ours and developing empathy towards them. It means the ability to respect other cultures. Besides, being eager to learn about other cultures is also intercultural competence. I can define it in that way (P4).

As can be seen in the excerpt, P4 mentioned nearly all of the concepts explored in the study such as the ability to communicate with people from other cultures, accepting similarities and differences, showing empathy and respect towards other cultures, and being open to learning about other cultures. In addition, knowledge of both the home and target culture was also expressed by other teachers. Finally, the teachers indicated that cultural knowledge and awareness were required to acquire a language and they specifically emphasized the paramount impact of English in intercultural communication in this globalized era while describing IC. 


\section{Teachers' understanding of an interculturally competent EFL learner}

When the teachers were asked to introduce the characteristics of an interculturally competent EFL learner, they indicated similar components that they mentioned while describing IC. These components included positive attitudes toward other cultures, including avoiding defensive and offensive behaviours toward others and being open and eager to learn about other cultures, as well as knowledge about the target and other cultures. Moreover, interactive and interpretative skills were also mentioned, which can be examined in Table 2.

\section{Table 2}

Participants' views on the characteristics of interculturally competent EFL learners

\begin{tabular}{lc}
\hline \multicolumn{1}{c}{ Categories and sample codes } & f \\
\hline 1. Attitudes & 32 \\
(e.g. empathy, tolerance, respect, openness, enthusiasm, lack of prejudices) & 12 \\
2. Knowledge & 6 \\
(e.g. knowledge of home, target and other cultures i.e. their cuisines, traditions, clothes, history, etc.) & 17 \\
3. Skills of interpreting and relating \\
$\quad$ (e.g. comparison between cultures, critical thinking, etc.) \\
4. Skills of discovery and interaction \\
$\quad$ (e.g. ability to communicate in English, adapting to other cultures easily, discovering some cultural elements \\
$\quad$ from TV series and movies.)
\end{tabular}

The teachers emphasized the attitudes that interculturally competent language learner should have. One of these attitudes was openness and eagerness to know other cultures and languages as can be seen in excerpt below.

A student must be open to other cultures as a foreign language learner. Instead of marginalizing people, and calling them 'giaour' as our elderly have called them before, they should be open to world cultures and eager to learn about these cultures. In addition to that, (a student) needs to know a foreign language and English seems to be the primary one as it is spoken everywhere in the world. However, I can define (an intercultural competent EFL learner) as the individuals who have not only learned English, but also have been eager to learn other languages and develop positive attitudes towards this issue (P2).

In addition to openness, some other teachers also emphasized the necessity of having empathy and respect for other cultures to be considered an interculturally competent learner. Tolerating and accepting differences between cultures were also specific attitudes that need to be developed by an interculturally competent learner according to the teachers.

With regard to the knowledge component, the teachers mainly indicated the importance of knowing about the culture of the target language, specifically knowing and being aware of behaviours, special days, cuisines, styles of clothing, and daily language of people who belong to that English culture as well as its history and traditions. However, there were also two teachers who indicated that learners should also be aware of popular cultures such as Korean culture since Korean TV shows and music are very popular nowadays.

Regarding the skills of the discovery and interaction category, ten teachers referred to the necessity of being competent in the English language, specifically being aware of their intonations, jokes, and colloquial language, and using them effectively while communicating with a foreigner.

When the teachers were asked whether their students were interculturally competent or not, 12 of the teachers indicated that they had mostly competent EFL learners whereas 11 of them indicated otherwise. There were also seven teachers who believed that they had a limited number of such students. When teachers were asked about their perceptions regarding their students' IC, they introduced certain reasons why they believe their students were competent or incompetent in terms of intercultural skills, which can be examined in Table 3 . 
Table 3

Rationale for having interculturally competent EFL learners

\begin{tabular}{lll}
\hline & Categories and sample codes \\
\hline 1. Attitudes &
\end{tabular}

(e.g. being eager, curious, and open to learn about other cultures, accepting differences between cultures, approaching other cultures positively, showing empathy)

2. Knowledge

(e.g. knowledge of target cultures i.e. festivals, special days, celebrities, songs, movies, and cuisines)

3. Skills of interpreting and relating

(e.g. sharing of what they have learned, heard, and experienced, reflecting intercultural elements in their assignments)

4. Skills of discovery and interaction

(e.g watching TV, using internet \& social media, playing computer /interactive games, being in contact with people from other cultures, proficiency in English and communicating effectively)

Teachers thought students were interculturally competent when they were enthusiastic and curious to learn other cultures and they did not have prejudices towards other cultures. Moreover, they exhibited IC when they had knowledge about other cultures, especially their festivals, celebrities, songs, movies, and cuisines.

Middle school students, especially 7th and 8th graders have intercultural competence. When we teach a song, mention a movie and royalty regarding English culture, or when we mention Easter and Christmas, they are not Greek to them anymore. They are aware of what they are. They just learn the new terms and read the texts regarding these (P27).

Some of the teachers believed that they had a limited number of interculturally competent students, but when they explained the reasons why they regarded some of their students as interculturally competent, it was obvious that these students were mainly the ones who favoured the use of technology and loved searching on the internet and interacting with other people, because teachers indicated that these students used social media and chat applications effectively, watched animations, listened to Korean music, and played online war games. That is, teachers believed these activities contributed to learners' IC development as they were exposed to language and had a chance to communicate with individuals from other cultures.

The teachers who believed that their students were interculturally incompetent provided some explanations regarding their experiences and observations in the classroom, which clearly illustrated their learners' lack of IC. The categories and sample codes are provided in Table 4.

\section{Table 4}

Rationale for not having interculturally competent EFL learners

1. Attitudes

(e.g. having prejudices about L2 learning, not being open and eager to learn about other cultures, having prejudices about other cultures, not accepting cultural differences, different lifestyles, marginalizing foreign students )

2. Knowledge

(e.g. a lack of knowledge of target/other/own cultures)

3. Skills of interpreting and relating

(e.g. not understanding other cultures/ differences between cultures, not understanding jokes in videos in the L2, reflecting only national elements in their assignments)

4. Skills of discovery and interaction

(e.g. not using English in their daily life, lack of English proficiency, not searching about the target culture much outside the class) 
With regard to attitudes, teachers expressed that their students had some prejudices toward foreign language learning. For instance, teachers mentioned that students were asking, 'Why do we learn English? Why don't we just learn our native language?' Some of the teachers also indicated that students only considered English classes just a course to pass.

The teachers indicated that students found other cultures strange when they encountered them in the textbooks. Similarly, P8 also indicated concerns and provided examples regarding what kinds of cultural values students regarded as strange.

\begin{abstract}
I have students who react in a variety of ways. For instance, when the behaviors that belong to British culture are mentioned, there are students who find them strange and say 'How ridiculous they are!'... In the simplest term 'fish and chips' and 'tea with milk' are mentioned in culture sections in every English course book. Whereas some of my students react to this saying, 'How can people drink tea with milk? That's nonsense! They do not even understand tea.' There are other students who say, 'What's wrong with that? I would like to try that too, it would be an interesting experience'(P8).
\end{abstract}

The teachers' concern was not only students' considering other cultures ridiculous but their lack of desire to learn about other cultures and English, and not being open to learning about other cultures. For instance, P14 specifically emphasized students' questions such as 'Why do we learn English? This (Halloween) does not exist in our culture. Why do we learn this?'

In addition to the lack of certain positive attitudes, openness, and eagerness to learn about other cultures, teachers also noted their students' lack of cultural knowledge. Moreover, some teachers acknowledged that their students had difficulty understanding cultural differences.

When all these experiences were considered, teachers had both interculturally competent and incompetent learners. However, what made them competent was primarily their knowledge of other cultures, their positive attitudes and lack of prejudices towards other cultures, and their engagement with other cultures. What made them incompetent was related to their lack of interest in learning and using English, lack of openness to learn about other cultures, considering learning them as meaningless, lack of knowledge, and lack of understanding of similarities and differences between cultures.

\title{
Teachers' understanding of an interculturally competent EFL teacher
}

The qualifications of an interculturally competent EFL teacher were similar to the characteristics of an interculturally competent learner, although they also included some skills regarding teaching or integrating IC in language classes, which can be scrutinized in Table 5.

When Table 5 was examined, it was obvious that teachers regarded positive attitudes as one of the most important criteria for being an interculturally competent teacher. Such attitudes primarily involved being open to other cultures, tolerating differences and respecting others' values, and not having prejudices toward other cultures. In addition, having empathy for other societies and being eager to learn about various cultures were also mentioned.

P2 especially emphasized the need for teachers to tolerate the differences and be open to other cultures before teaching it to their students. She claimed that it would be hard to expect learners to tolerate a foreign culture if teachers could not tolerate varieties in their own culture. P29 also indicated the significance of tolerating and accepting differences, specifically emphasizing the meaningless of stereotyping others.

If a teacher can tolerate everything in that stage, this might be religious beliefs, clothing, behaviors, etc. I expand culture in that way. I do think that way. If we can act thoughtfully to the people who are conservative, open-minded, or if we can look at religionist, unbelievers, and the secular from a respectful point of view, then we can raise our children, the next generation, accordingly. This is included in intercultural competence. You know, it counts as nothing whether you are turbaned, you pray, you are an atheist or you have a body full of tattoos or piercings overseas. Interlocutors' style is not important at all (P29). 
Table 5

Participants' views on the characteristics of interculturally competent EFL teachers

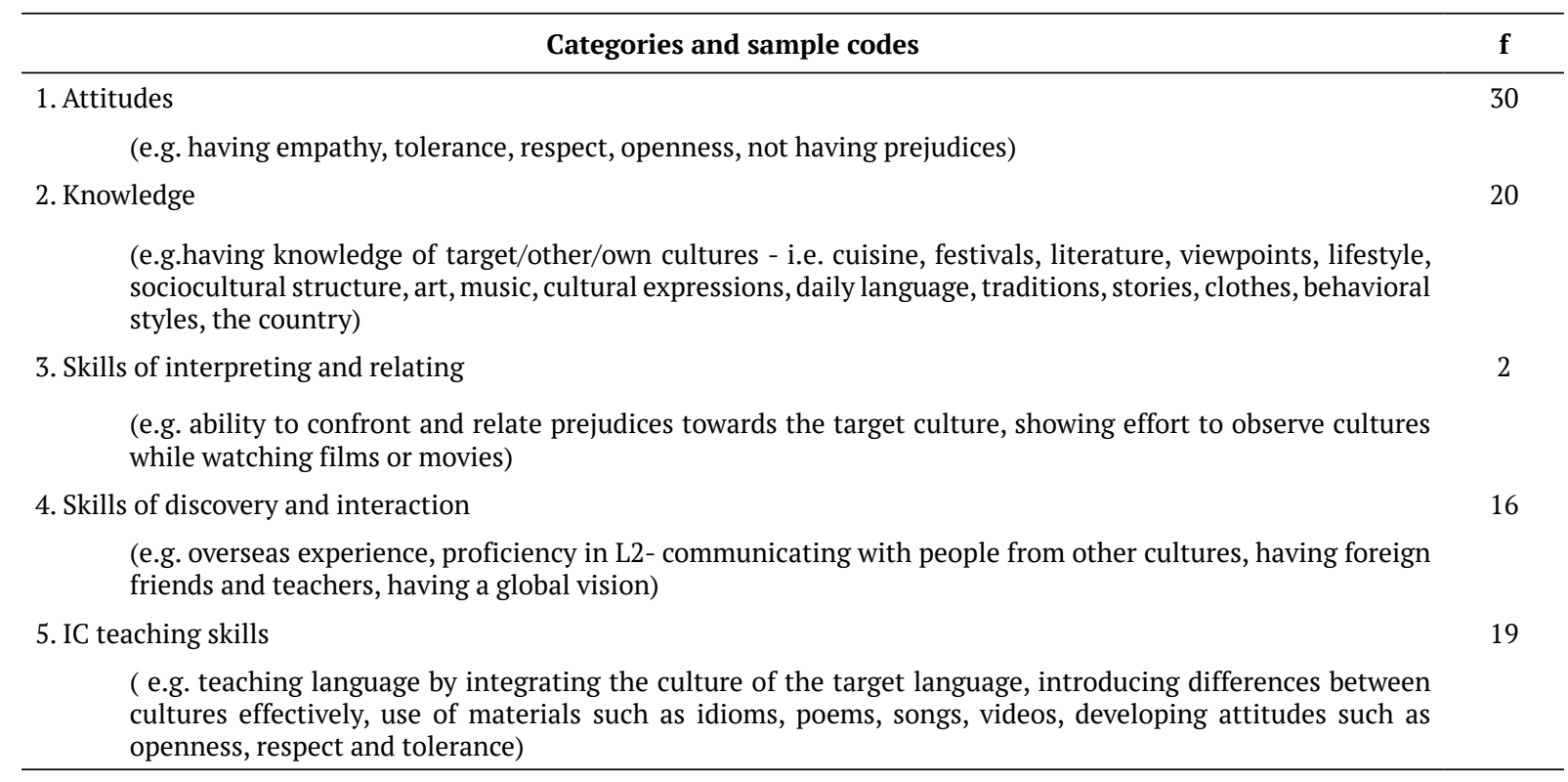

Attitudes were not the only characteristics of interculturally competent EFL teachers. Knowledge about one's own culture, as well as target and other cultures was also a prerequisite for being a competent EFL teacher. For instance, P14 put emphasis on the effort to know about other cultures, either by visiting other countries and cultures or seeing movies that belong to those cultures.

Teachers also believed that an interculturally competent EFL teacher should be able to communicate well in the target language that they are teaching. Specifically, a teacher was expected to be able to maintain a conversation with foreign speakers and have knowledge of how to use words, phrases, and idioms.

Teachers also believed in the necessity of having overseas experience to develop teachers' IC. For instance, one teacher indicated that the more a teacher knew about other societies and cultures, the more they would contribute to their language learners.

Finally, having skills to integrate culture in language classrooms, the ability to introduce differences between cultures, and the ability to develop learners' attitudes such as openness and tolerance were also some of the traits mentioned.

Teachers were asked to evaluate their own IC development and 15 of them felt mostly interculturally competent. Eight of these were working in high schools, six of them were working in middle schools, and one was teaching in both contexts. The teaching experiences of these teachers also varied. Six of them had 0-5 years of teaching experience, five of them had 6-10 years, and four of them had 11-21 years.

However, there were also teachers who felt incompetent and 'not necessarily' competent. Seven of these were working in high schools and six were teaching in middle schools. Two of these had less than five years of teaching experience, six of them had 6-10 years, and five of them had 11-19 years.

As shown in Table 6, teachers' attitudes made them believe they were competent. Teachers believed that they were open to learn and teach other cultures, cultural differences, and new ideas. Tolerance and respect for other cultures were also some of the qualifications that the EFL teacher participants possessed. Teachers also considered themselves to be interculturally competent inasmuch as they knew or tried to learn about the target culture and did not have much difficulty in responding to students' queries about the target culture. A few of them also indicated that they had no difficulty interpreting the message in the target language. 
Table 6

Rationale for being an interculturally competent EFL teacher

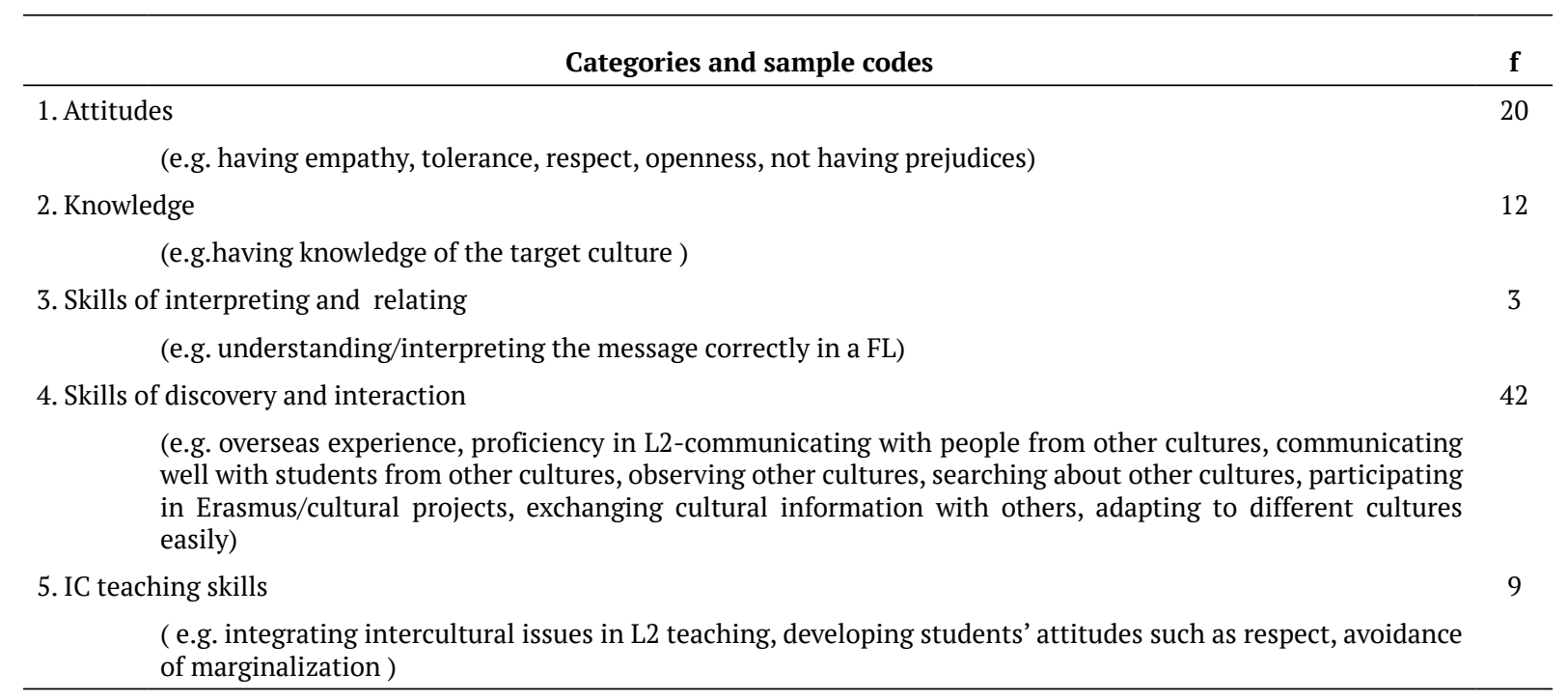

Some of the most frequently mentioned reasons why teachers felt interculturally competent were the ability to communicate with people from other cultures, having overseas experience, and observing other cultures during visits abroad.

For instance, I can communicate with people who are native speakers of English. I can also communicate with my friends who speak foreign languages. I can exchange information about cultures. I can communicate effectively. Besides, TV series and movies that I watch in foreign language teach me many things. Therefore, I believe I know the culture of the target language that I teach. However, if I have a chance to go abroad and learn more, I believe I would learn more about the target culture (P4).

As P4 expressed, having experience abroad is an impactful factor in teachers' feelings of competence when intercultural knowledge is considered. P19 especially emphasized his overseas experience when indicating the reasons why he felt interculturally competent. He said that he had been to America twice and reported having observed the lifestyles of people living there. He indicated his confidence when he responded to the students' questions about the target culture. However, among the 15 teachers who considered themselves competent, there were six teachers who did not have any overseas experience.

On the other hand, one third of the teachers reported that they did not view themselves as interculturally competent. The reasons for their incompetency were primarily their lack of knowledge about the target and other cultures, lack of overseas experience, lack of training on IC, and limited resources to teach IC as demonstrated in Table 7.

Regarding the lack of knowledge, P26 explained the ways in which she lacked knowledge about the target culture.

For instance, there are the life experiences, rituals, traditions, and reactions of people who live in the countries where English is spoken. I do not know much about them. I still try to learn by reading. Therefore, I do not consider myself to be competent. I can never say that I am competent. That would be to overstep my bounds (P26).

A lack of knowledge about the target culture and other cultures was not the only reason for teachers' viewed incompetence in relation to intercultural learning and teaching as shown in Table 7. Just as the participant EFL teachers pointed to overseas experience as something that made them feel interculturally competent, the teachers who expressed themselves as incompetent also indicated their lack of overseas experience as one of the reasons why they felt incompetent. 
Table 7

Rationale for not being an interculturally competent EFL teacher

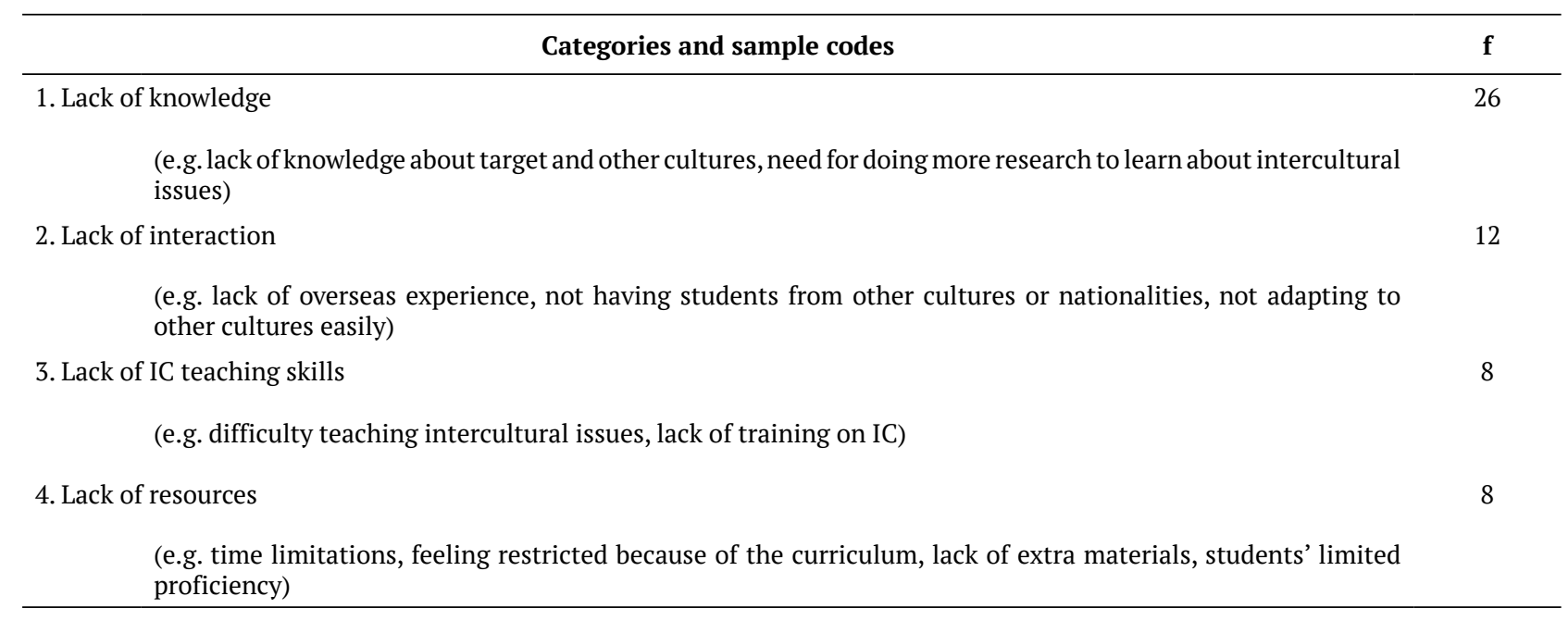

Teachers also believed that their difficulty explaining intercultural issues in the classroom, lack of training on IC, and not having a chance to do interactive activities like role plays and dramas were some of the reasons they considered themselves incompetent in terms of IC. Even though the frequency of the codes was low, the teachers also mentioned time limitations, curriculum requirements, a lack of materials, and students' low proficiency in English.

As a result, EFL teachers considered an interculturally competent EFL teacher to be an individual who is open and eager to learn about other cultures and someone who is knowledgeable about the target and other cultures. In addition, the ability to communicate with people from other cultures effectively, tolerating differences, and having overseas experience were also some characteristics that an IC teacher needed to possess. Half of the teachers thought that they were competent whereas others did not feel the same way. The reasons provided for their perceptions of competency or incompetency confirmed what they described as the characteristics of an interculturally competent teacher.

\section{Discussion}

\section{Intercultural competence in the eyes of EFL teachers}

There are various definitions of IC in the literature; however, it is hard to develop strategies and materials to enhance it when there are too many different understandings of the same concept. Therefore, Deardorff (2006) conducted a Delphi study by polling experts in the field of intercultural communication so that a compromise could be reached regarding the definition of IC. On the other hand, teachers are the ones who implement intercultural learning and teaching in their classrooms. Therefore, it is also important to know what they really understand about IC to interpret their practices and needs thoroughly. This study primarily aimed to reveal teachers' own definitions and understanding of IC. The teachers' definitions were primarily in accordance with what was suggested in the literature as they referred to cognitive, affective, and behavioural skills to be able to communicate with people from different cultures.

The teachers' most frequently given definition was very close to the most accepted definition of IC in the literature, which is 'the ability to interact effectively and appropriately in intercultural situations' (Byram, 1997; Deardorff, 2006; Fantini, 2009, Hismanoğlu, 2011; Sercu, 2005). The ability to interact with others is referred as the 'desired external outcome' in Deardorff's (2006) pyramid model of IC whereas it was classified under the title of 'skills of interaction and discovery' in Byram's (1997) Intercultural Competence Model. However, as it is framed in various studies, the ability to communicate with others is a commonly accepted component of IC. A few teachers also defined IC as adapting to other cultures and environments and exhibiting culturally appropriate behaviours in intercultural situations. In this regard, this definition was compatible with one of the desired 
external outcomes of Deardorff's (2006) Process Model of Intercultural Competence, and fifth stage of Bennett and Bennett's (2004) Developmental Intercultural Competence Model, which is adaptation.

The teachers also highly praised the place of English in the international agenda. Since English was seen as an international language by the teachers, they emphasized the importance of the use of English for interactions with people from other cultures. Therefore, it can be said that the aim of English language teaching was not regarded as developing native-like output but intercultural speakers (Aguilar, 2008; Alptekin, 2002; Bayyurt, 2006; Byram \& Zarate, 1994; Byram, 2008; Corbett, 2003; Kramsch, 1998; Risager, 2007; Selvi, 2014, Wilkinson, 2012).

The teachers also emphasized the significance of culture in language learning and explained its positive impact on learners' language development. As Crozet and Liddicoat's (1997) explained, 'There is no language use without culture and that culture is central to communication' (p. 15). Moreover, the teachers particularly referred to the inseparability of culture and language, which was also mentioned by the teacher participants in Bayyurt's (2006) study. Her participants were also aware of the impossibility of teaching a language without making learners aware of that cultural mind-set. Baker (2011) also claimed that it was strenuous to teach a language irrespective of the cultural context because of the inseparability of language and culture.

Teachers' definition of IC included one of the common components suggested in the literature, which is 'knowledge'. The 'knowledge' component was mentioned in many IC models, such as Byram's (1997) Intercultural Competence Model, Deardorff's (2006) Process Model of Intercultural Competence and Pyramid Model of Intercultural Competence, and finally Ting-Toomey and Kurogi's (1998) Facework-based Model of Intercultural Competence. In this particular study, the knowledge component was mostly explained with special days, lifestyles, clothes, cuisine, religion, cultural heritage, and habits of the target cultures. In other words, it did not just include Big C elements. This finding was similar to Bayyurt's (2006) study as the teachers' definition of culture included all these elements. As Byram, Gribkova, and Starkey (2002) and Hatipoğlu (2012) indicated, knowledge of the target culture was regarded as the prerequisite for language proficiency in the target language.

However, it should be noted that participants also emphasized the knowledge of one's own native culture for IC. As many other researchers (Alptekin, 2002, Corbett, 2003; Ho, 2009; Kaçar, 2019; Kızılaslan, 2010; McKay, 2002) indicated, students' native language has a significant role in intercultural language learning and teaching. As Byram and Wagner (2018) claimed, knowledge and understanding of other societies requires understanding and knowledge of one's own society first.

In their definitions of IC, the teachers also referred to certain personal characteristics such as having empathy for others, respecting other cultures, and differences between cultures and being open and enthusiastic to learn about other cultures and societies. Therefore, the findings were similar to Brunsmeier's (2017) study in the German context. In Deardorff's (2006) Delphi study, one component suggested for IC was also personal characteristics of people such as curiosity, openness, and respect for other cultures. Deardorff (2006) also named it under the title of 'attitudes' in the Process Model of IC. The characteristics mentioned (i.e. empathy, respect, and openness) were also congruent with the 'attitudes' component of IC suggested by Byram's Intercultural Competence Model (1997, 2008, and 2012). This also supports Elena's (2014) definition of IC as being open to other cultures and accepting cultural differences. The EFL participant teachers also highlighted the importance of understanding other cultures besides the target culture. 'Understanding others' world views' was also fully acknowledged as a component of IC in Deardorff's (2006) study as well.

To summarize, the results of the study indicated that even though not all of the participant teachers developed a complete understanding of IC or conceptualized an in-depth definition, they mentioned the components referring to various models suggested in the literature. Over half of the teachers mentioned the ability to communicate in English, which is part of the behavioural aspect, and emphasized the inseparability of culture and language and the international status of English. Slightly less than half of them referred to knowledge of the target cultures, which is part of the cognitive aspect and attitudes, an affective dimension of IC. One third of them mentioned the skills of interpreting and relating. There were very few teachers who mentioned all of the dimensions of IC. 


\section{Teachers' understanding of an interculturally competent EFL learner}

The participants believed that an interculturally competent EFL learner was an individual who is open to other cultures and someone who accepts differences between various societies and has empathy for others. Therefore, the findings were in line with Jackson's characteristics of intercultural communicators and Fantini's (2000) profile of an interculturally competent person. Having such attitudes was believed to lead to the willingness to explore and probe into other perspectives and modes of life that are different from the students' traditional comfort zone that they were raised in and bring about new perspectives and experiences (Council of Europe, 2016).

Ten teachers in the study also thought that a language learner who is interculturally competent should be proficient in English. This finding supported Elena's (2014) and Aba's (2016) claim that proficiency in English is a passport for intercultural competence. In addition, Baker and Fang (2020) indicated that students who had study abroad experience also associated competency in the English language with the development of intercultural citizenship. Porto (2019) also reported that intercultural education in an international project contributed to English language learning. Consequently, recent studies demonstrate how the intercultural dimension and English language proficiency are conducive to one another.

Knowledge of both one's own culture and the target culture was considered necessary for being an interculturally competent EFL learner. Three teachers described an effective EFL learner as someone who has the ability to compare their own native culture with other cultures. As East (2008) indicated, intercultural ability is not just a connection between language and culture, or the cultural facts acquired, but also a comparison of these facts across cultures and accommodating oneself in intercultural encounters where we name the interlocutors as 'others'.

An important finding in this regard was that only 12 teachers indicated that their students were interculturally competent. Two of these teachers indicated that their students were competent but not all the time and not completely. Eight of these teachers reported that they were interculturally competent as well. The teaching experiences of these teachers ranged between four and 21 years. Half of them were teaching in a middle school and half were teaching in a high school.

The other 18 teachers believed that their students were incompetent or they had a limited number of interculturally competent students. Half of these teachers were ones who regarded themselves as incompetent. Students' prejudices about learning English and learning about other cultures were some of the reasons that were revealed during the interviews. This might be an important contributor to the teachers' awareness of their students' needs. Since they know what is missing in their students' repertoire in terms of intercultural skills, they can develop strategies and materials to counter such attitudes and behaviours. They can even go deeper to help learners face the realities of the world outside the classroom with intercultural conflict cases and ask them to introduce possible solutions for these so that they can realize how important IC is for their lives.

To summarize, the majority of the teachers somewhat understood what constituted a competent intercultural speaker and they knew whether their students had these characteristics or not. They were able to express why they regarded their students as competent or incompetent and it was obvious that some teachers had both interculturally competent and incompetent students even though the proportion might vary.

\section{Teachers' understanding of an interculturally competent EFL teacher}

The teachers also listed the characteristics of an interculturally competent EFL teacher. However, their opinions with respect to whether they were interculturally competent or not were consulted.

As demonstrated in Figure 2, the results of this study indicated that an interculturally competent EFL teacher had various qualities. To reiterate, one of the most frequently mentioned traits was the necessity of being open to other cultures and respecting other cultures and cultural differences. Therefore, the teachers' understanding of an interculturally competent EFL teacher was very similar to the qualifications of an intercultural teacher mentioned by Marczak (2013) and Brunsmeier (2017), and the competences indicated in MoNE's (2017) General Competencies for Teaching Profession. Therefore, an interculturally skilful EFL teacher is to be open-minded, value otherness, and have respect for the values of other cultures. Moreover, the teachers who believed that 
they were interculturally competent also mentioned that they had positive attitudes towards other cultures, have respect and empathy for individuals from other societies.

\section{Figure 2}

Qualifications of an interculturally competent EFL teacher suggested by the participants of the study

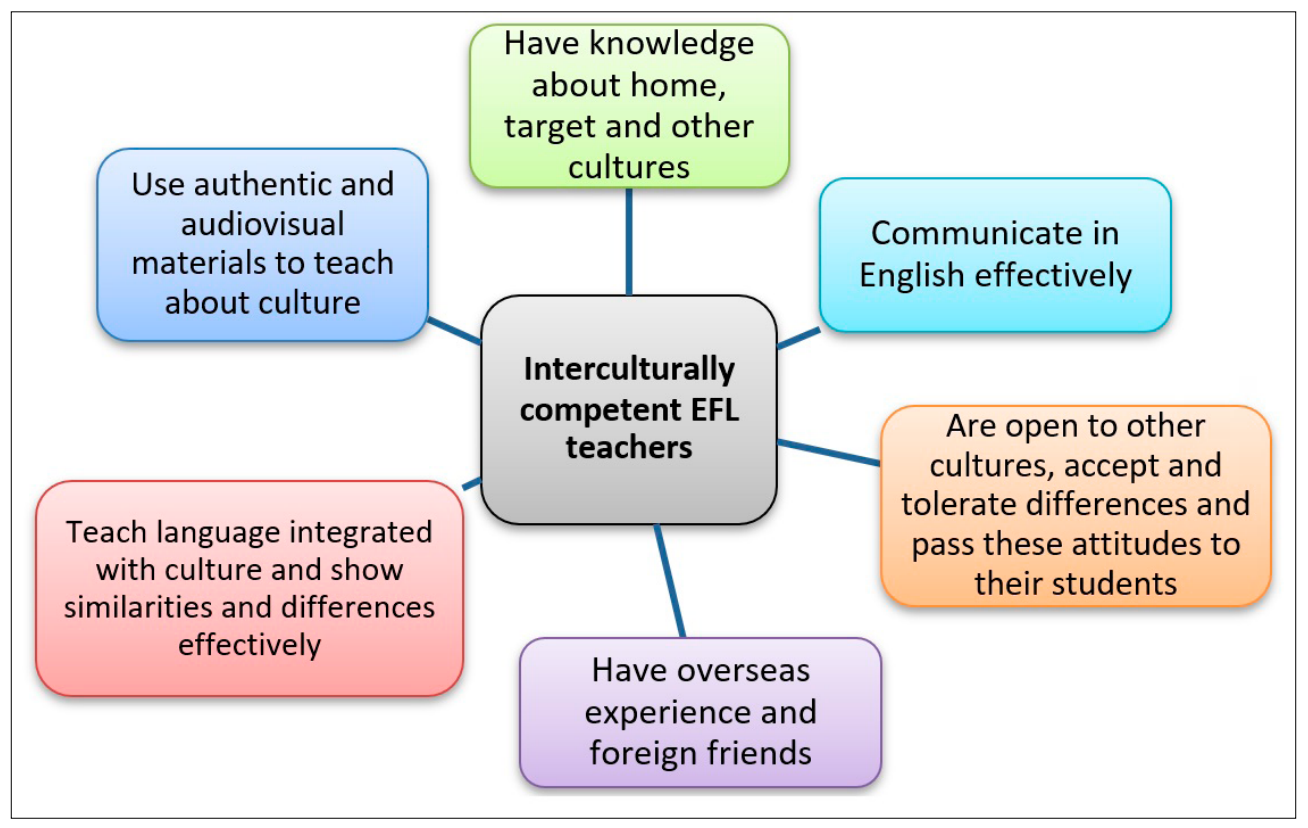

Another finding of the study was that an interculturally competent teacher was believed to have a sufficient amount of knowledge about native, target, and other cultures so that they could easily respond to students' queries about different cultures, which was also mentioned in Marczak (2013). The teachers in this study primarily emphasized the need for knowledge regarding the culture of the societies where the target language, i.e. English, is spoken. Teachers who regarded themselves as interculturally competent also thought that they had adequate knowledge about the target culture, which was in line with the result of Kılıç's (2013) study because instructors in that study also found their target culture knowledge to be quite satisfactory. However, knowledge of cultural practices and products of their own native culture was also considered important by the teachers so that they could provide sensible comparisons regarding the variation among other cultures. So, the teachers' views were in line with Ho's (2009), Kızılaslan's (2010), and Kaçar's (2019) claims regarding the significance of knowledge of the teachers' own native culture in order to promote intercultural competence for language learners.

There were also teachers who specifically indicated that they did not define or consider IC in terms of being aware of the target culture only since they were aware of the importance of ELF and English as an international language in terms of teaching of English. Therefore, they emphasized the need for knowledge of other cultures. There is still a strong view that culture teaching might start with the familiar, one's own culture, and move to native speaker English culture; however; another option might involve the transition from one's own culture to the international English culture, which might include the culture of English varieties, pop culture, travel culture, etc. (Alptekin, 1993). As Perez Gracia, Serrano Rodríguez, and Carpio (2020) indicated, it is necessary to equip learners with the competencies to become citizens of globalised world, which can be achieved via content and language integrated learning.

The participant teachers primarily emphasized the skills and methods of integrating culture in language classrooms and introducing differences between cultures efficiently. The use of certain materials to promote IC skills (Marczak, 2013) was also referred to as one of the qualifications of successful intercultural teachers.

The teachers emphasized having intercultural contact through overseas experiences to be interculturally competent EFL teachers. They also affirmed that an interculturally competent EFL teacher can easily and effectively communicate with people from other cultures. Marczak (2013) also underlined the need for an 
intercultural teacher to excel in the foreign language so that they could have the role of a mediator and cope with the authentic language explored in various media tools. The teachers who believed that they were interculturally competent were also confident that they could effectively communicate with foreigners. Out of the 15 teachers who believed they were competent, eight of them had less than one month of overseas experience and one of them has been to America one to three months. Although the opportunities to go abroad have multiplied in recent years, many teachers might still lack overseas experience. For instance, half of the teachers who felt interculturally incompetent had no overseas experience and introduced this as a reason why they regarded themselves as incompetent.

In addition to a lack of overseas experience, another reason for their feelings of inadequacy was primarily related to their lack of knowledge, which were very similar to the findings of Atay (2005) and Larzén-Östermark's (2008) study as the teachers did not have many insights into cultural aspects and the proper ways to address them in their teaching. Han and Song (2011) also noted that when students asked about an unfamiliar cultural element in the text, and teachers were not able to respond to this inquiry in an Asian context, that would put the teachers in a really troubling situation since teachers were seen as the knowledge providers in that context. As Schulz (2007) elucidated, it might not be very difficult for the teacher to understand the culture-specific information about the target culture like products and practices, but it might be unrealistic for them to see the effect of the cultural perspectives on these products and practices inasmuch as this requires background information.

A lack of teaching sources was also mentioned during the interviews as one of the factors that caused teachers to feel incompetent. In previous studies in the Turkish context (Demircioğlu, \& Çakır, 2015; Kahraman, 2016; Korkmazgil, 2015), it was also acknowledged that there were insufficient materials and limited sources for language teaching. As Han and Song (2011) asserted, teachers want to have chances for more intercultural interactions, ample teaching materials and resources, and professional training in regard to connecting culture and language in language teaching.

To summarize, teachers' perceptions in relation to the characteristics of an intercultural EFL teacher were similar to the characteristics of an interculturally competent EFL learner and the components of IC. In addition, they needed to have the skills, strategies, materials, and activities to pass intercultural competences on to their students. Even though half of the teachers regarded themselves as competent, the other half either stated that they were not competent at all or they were not sure about it. Therefore, there is a need for teachers to be trained, guided, and supported in terms of intercultural skills.

\section{Conclusion}

The purpose of the study was to explore public middle and high school English language teachers' understanding of intercultural competence and shed some light on this issue as there were only a limited number of research studies in this context. The findings revealed that the teachers emphasized the interrelation between language and culture and the importance of English as an international language. They viewed IC as the ability to communicate with people from other cultures effectively, have knowledge about one's own, target, and other cultures, and develop positive attitudes toward other cultures and societies. However, while defining IC, few teachers referred to all of the dimensions of IC suggested in the literature. The teachers' definition primarily emphasized the ability to communicate with individuals from other cultures. The study was limited in that it only queried state school EFL teachers' definition of IC and the number of the participants was limited to 30. However, it might provide some insight for researchers regarding the concept of IC in the Turkish context, and the study is also significant as it revealed the reasons why some teachers felt incompetent in terms of integrating IC in their classrooms. Further studies that assess teachers' IC rather than their self-assessment could be conducted. Additionally, other studies might probe into teachers' IC teaching in actual language classrooms via observations. Furthermore, in-service training programs where teachers are guided in terms of what IC involves and how it can be integrated into language classrooms can be developed to assist language teachers in the process of IC teaching. 


\section{Conflict of interest}

The authors declare that they have no conflict of interest.

\section{References}

Aba, D. (2016). Addressing intercultural experience and academic mobility in higher education. Journal of Intercultural Communication Research, 45(6), 487-592. https://doi.org/10.1080/17475759.2016.1236032

Aguilar, M. J. C. (2008). Dealing with intercultural communicative competence in the foreign language classroom. In E. Alcon Soler \& M. P. Safont Jorda (Eds), Intercultural language use and language learning (pp.59-78). Springer.

Alptekin, C. (1993). Target-language culture in EFL materials. ELT Journal, 47(2), 136-143. https://doi. org/10.1093/elt/47.2.136

Alptekin, C. (2002). Towards intercultural communicative competence in ELT. English Language Teaching Journal, 56 (1), 57-64. https://doi.org/10.1093/elt/56.1.57

Atay, D. (2005). Reflections on the cultural dimension of language teaching. Language and Intercultural Communication, 5(3-4), 222-236. https://doi.org/10.1080/14708470508668897

Baker, W. (2011). From cultural awareness to intercultural awareness: Culture in ELT. ELT Journal, 66(1), 66-70. https://doi.org/10.1093/elt/ccr017

Baker, W., \& Fang, F. (2020). 'So maybe I'm a global citizen': Developing intercultural citizenship in English medium education. Language, Culture and Curriculum, 1-16. https://doi.org/10.1080/07908318.2020.1748045

Bayyurt, Y. (2006). Non-native English language teachers' perspective on culture in English as a Foreign Language classrooms. Teacher Development, 10(2), 233-247. https://doi.org/10.1080/13664530600773366

Behrnd, B., \& Porzelt, S. (2012). Intercultural competence and training outcomes of students with experiences abroad. International Journal of Intercultural Relations, 36, 223-233. https://doi.org/10.1016/j. ijintrel.2011.04.005

Bennet, J. M. \& Bennet, M. J. (2004). Developing intercultural sensitivity: An integrative Approach to global and domestic diversity. In D. Landis, J.M Bennett, \& M.J. Bennett (Eds.), Handbook of Intercultural Training (pp.145-167). Sage

Byram, M. (1997). Teaching and assessing intercultural competence. Multilingual Matters.

Byram, M. (2008). From foreign language education to education for intercultural citizenship: Essays and reflections, Multiple Matters.

Byram, M. (2012). Conceptualizing intercultural (communicative) competence and intercultural citizenship. In J.Jackson (Ed.), The Routlege handbook of language and intercultural communication. Routledge.

Byram, M., Gribkova, B., \& Starkey, H. (2002). Developing the intercultural dimension in language teaching: A practical introduction for teachers. Council of Europe.

Byram M., \& Wagner, M. (2018). Making a difference: Language teaching for intercultural and international dialogue. Foreign Language Annals, 51, 140-151. https://doi.org/10.1111/flan.12319

Byram, M., \& Zarate, G. (1997). Definitions, objectives and assessment of sociocultural competence. In Sociocultural competence in language learning and teaching (pp. 7-43). Council of Europe.

Canale, M., \& Swain, M. (1980). Theoretical bases of communicative approaches to second language teaching and testing. Applied Linguistics, 1, 1-47. https://doi.org/10.1093/applin/I.1.1

Cansever, Z. M. \& Mede, E. (2016). Perceptions of native and non-native EFL instructors' in relation to intercultural foreign language teaching. Abant İzzet Baysal Üniversitesi Eğitim Fakültesi Dergisi, 16(1), 75-94.

Catalano, T. (2014). Boosting intercultural competence in a teacher education course. Proceedings of the Intercultural Competence Conference (vol. 3, pp. 22-45).

Corbett, J. (2003). An intercultural approach to English language teaching. Multilingual Matters.

Council of Europe. (2016). Competences for Democratic Culture (CDC): 559 validated descriptors. Council of Europe.

Crozet, C., \& Liddicoat, A.J. (1997). Teaching culture as an integrated part of language teaching: An introduction. Journal of Australian Applied Linguistics, Series S, 14, 1-22. https://doi.org/10.1075/aralss.14.01cro

Deardorff, D.K. (2006). Identification and assessment of intercultural competence as a student outcome of internationalization. Journal of Studies in International Education, 10(3), 241-266. https://doi. 
org/10.1177/1028315306287002

Deardorff, D. K. (2009). Implementing intercultural competence assessment. In D. K. Deardorff (Ed.), The SAGE Handbook of Intercultural Competence (pp. 477-491). Sage.

Demircioğlu, Ş., \& Çakır, C. (2015). Intercultural competence of English language teachers in International Baccalaureate World Schools in Turkey and abroad. Journal of Language and Linguistic Studies, 11(1), 15-32.

Doğançay-Aktuna, S. (2005). Intercultural communication in English language teacher education. ELT Journal, 59(2), 99-107. https://doi.org/10.1093/eltj/cci023

Dwyer, M. M. (2004). More is better: The impact of study abroad program duration. Frontiers: The Interdisciplinary Journal of Study Abroad, 10,151-164.

East, M. (2008). Moving towards 'us-others' reciprocity: Implications of glocalisation for language learning and intercultural communication. Language and Intercultural Communication, 8(3), 156-171. https://doi. org/10.1080/14708470802167776

Elena, S. (2014). The 'intercultural' teacher- a new response to the teaching career.Procedia-Social and Behavioral Sciences, 128, 111-116. https://doi.org/10.1016/j.sbspro.2014.03.127

Fantini, A. E. (2000). A central concern: Developing intercultural competence. SIT Occasional Paper Series ( $p p$. 25-42). School for International Training.

Fantini, A. E. (2009). Assessing intercultural competence. In D.K. Deardorff (Ed.), The SAGE handbook of intercultural competence (pp. 456-476). Sage.

Ghanem, C. (2017). Teaching intercultural communicative competence: The perspective of foreign language graduate students instructors. International Journal for the Scholarship of Teaching and Learning, 11(2), 1-9. https://doi.org/10.20429/ijsotl.2017.110209

Hammer, M. R. (2015). Intercultural competence development. In J.M. Bennett (Ed.), The SAGE encyclopedia of intercultural competence (pp. 483-486). Sage.

Han, X., \& Song, L. (2011). Teacher cognition of intercultural communicative competence in the Chinese ELT context. Intercultural Communication Studies, 20(1), 175-192.

Hatipoğlu, Ç. (2012). British culture in the eyes of future English language teachers in Turkey. In Y. Bayyurt \& Y. Bektas-Çetinkaya (Eds.), Research perspectives on teaching and learning English in Turkey: Policies and Practices (pp. 119-144). Peter Lang.

Ho, S. T. K. (2009). Addressing culture in EFL classrooms: The challenge of shifting from a traditional to an intercultural stance. Electronic Journal of Foreign Language Teaching, 6(1), 63-76.

Hymes, D. H. (1972). On Communicative Competence. In J.B. Pride \& J. Holmes (Eds.), Sociolinguistics. Selected Readings (pp. 269-293). Penguin.

Jackson, J. (2014). Introducing Language and Intercultural Communication. Routlege.

Kaçar, M. (2019). The place of native culture in the intercultural training of pre-service English language teachers: The Turkish case (Unpublished Master's thesis). Middle East Technical University.

Kahraman, A. (2016). Teachers' and learners' attitudes towards culture and culture learning in a Turkish context. Journal of Language and Linguistic Studies, 12(2), 1-12.

Kılıç, S. (2013). English lecturers' beliefs regarding intercultural competence. Hasan Ali Yücel Eğitim Fakültesi Dergisi, 20(2), 47-59.

Kızılaslan, I. (2010). Yabanci dil ögretmen yetistirme sürecinde kültürlerarasilik [Intercultural in the process of training foreign language teachers]. Milli Eğitim Dergis, 40(185), 81-89.

Korkmazgil, S. (2015). An investigation into Turkish English language teachers' perceived professional development needs, practices and challenges (Unpublished Doctorate Dissertation). Middle East Technical University.

Kramsch, C. (1993). Context and culture in language education. Oxford University Press.

Kramsch, C. (1998). Language and culture. Oxford University Press.

Kuru Gönen, S. I., \& Sağlam, S. (2012). Teaching culture in the FL classroom: Teachers' perspectives. International Journal of Global Education, 1(3), 26-46.

Larzén-Östermark, E. (2008). The intercultural dimension in EFL-teaching: A study of conceptions among Finland-Swedish comprehensive school teachers. Scandinavian Journal of Educational Research, 52(5), 527547. http://doi.org/10.1080/00313830802346405

Marczak, M. (2013). Communication and information technology in (intercultural) language teaching. Cambridge Scholars Publishing.

Ministry of National Education (MonE). (2017). General competencies for teaching profession. Directorate General for Teacher Training and Development.

Moeller A. J., \& Faltin Osborn, S. R. (2014). A pragmatist perspective on building intercultural communicative competency: From theory to classroom practice. Foreign Language Annals, 47, 669-683. https://doi. 
org/10.1111/flan.12115

Mughan, T. (1999). Intercultural competence for foreign languages students in higher education. Language Learning Journal, 20(11), 59-65. https://doi.org/10.1080/09571739985200281

Perez Gracia, E., Serrano Rodríguez, R., \& Carpio, A.J. (2020). Promoting interculture through content and competences within bilingual education: Teachers in action. Intercultural Education, 1-20. https://doi.org/ 10.1080/14675986.2020.1747348

Pietkiewicz, I., \& Smith, J. A. (2012). A practical guide to using interpretative phenemonological analysis in qualitative research psychology. Psychological Journal, 18(2), 361-369. https://doi.org/10.14691/CPPJ.20.1.7

Porto, M. (2019). Does education for intercultural citizenship lead to language learning? Language, Culture and Curriculum, 32(1), 16-33. https://doi.org/10.1080/07908318.2017.1421642

Rathje, S. (2007). Intercultural competence: The status and future of a controversial concept. Language and Intercultural Communication, 7(4), 254-266. https://doi.org/10.2167/laic285.0

Risager, K. (2007). Language and culture pedagogy: From a national to transnational paradigm. Multilingual Matters.

Schulz, R. A. (2007). The challenge of assessing cultural understanding in the context of foreign language instruction. Foreign Language Annals, 40(1), 9-26. https://doi.org/10.1111/j.1944-9720.2007.tb02851.x

Selvi, A. F. (2014). Myths and misconceptions about nonnative English speakers in the TESOL (NNEST) movement. TESOL Journal, 5(3), 573-611. https://doi.org/10.1002/tesj.158

Sercu, L. (2005). Teaching foreign languages in an intercultural world. In L. Sercu et al. (Eds.), Foreign language teachers and intercultural competence: An international investigation (pp.1-18). Multilingual Matters.

Sercu, L. (2006). The foreign language and intercultural competence teacher: The acquisition of a new professional identity. Intercultural Education, 17(1), 55-72. https://doi.org/10.1080/14675980500502321

Spitzberg, B. H., \& Changnon, G. (2009). Conceptualizing intercultural competence. In D.K. Deardorff (Ed.), The SAGE handbook of intercultural competence (pp. 2-52). Sage.

Ting-Toomey, S., \& Kurogi, A. (1998). Facework competence in intercultural conflict: An updated facenegotiation theory. International Journal of Intercultural Relations, 22(2), 187-225. https://doi.org/10.1016/ S0147-1767(98)00004-2

Wilkinson, J. (2012). The intercultural speaker and the acquisition of intercultural/global competence. In J. Jackson (Ed.), The Routlege Handbook of Language and Intercultural Communication. Routledge. 